\title{
Ecofriendly and Innovative Processing of Hemp Hurds Fibers for Tissue and Towel Paper
}

\author{
Ved Naithani, Preeti Tyagi, Hasan Jameel, Lucian A. Lucia, and Lokendra Pal * \\ An innovative approach for preparing hemp fibers from hemp hurds for \\ use in tissue and towel grades of paper is described. Hemp hurds are a \\ low value by-product of industrial hemp processing that are generally used \\ for animal bed litter. Tissue paper was fabricated from hemp hurd fibers \\ by following three pulping processes: autohydrolysis (hydrothermal), \\ sodium carbonate-based defibration, and high yield kraft pulping, and \\ benchmarked against hardwood pulp. To meet industrial standards, \\ hardwood and hemp pulp fibers were mixed at a dry mass ratio of 75:25, \\ from which tissue paper sheets were prepared. Desirable tissue paper \\ properties, such as water absorption, burst resistance, softness, and \\ tensile strength (dry and wet), were measured and compared. \\ Characterization of morphological and chemical properties of tissue \\ handsheets was conducted with SEM and time-of-flight-secondary ion \\ mass spectrometry (ToF-SIMS). The combined kraft pulped hardwood \\ and autohydrolyzed hemp pulp fibers displayed improvements in tensile \\ index, burst resistance, and softness of tissue handsheets compared to \\ only kraft hardwood pulp handsheets without adversely impacting water \\ absorption. Hardwood fibers showed a sparse distribution of surface lignin \\ compared to hemp fibers using the same defibration. This technology can \\ lead to a variety of eco-friendly tissue paper products that are not only \\ highly energy efficient, but avoid harsh chemical processing.
}

Keywords: Industrial hemp fibers; Hemp hurds; Autohydrolysis; Carbonate hydrolysis; High yield kraft pulping; Tissue and towels papers; Sustainable brown tissue and towels

Contact information: Department of Forest Biomaterials, North Carolina State University, Box 8005, Raleigh, NC 27695-8005, USA; *Corresponding author: Lokendra_pal@ncsu.edu

\section{INTRODUCTION}

The demand for paper in household hygiene products, including tissue papers, hand towels, napkins, wipes, etc., is continuously increasing due to increased health awareness and low costs (Richard 2003; Trent 2019). Although paper is sustainable in all forms, various economic, social, and scientific factors make balancing sustainability and profitability a challenge for the paper industry (Diesen 1998). The main challenge in producing sustainable cellulose fibers is ensuring that the source of these fibers is based on sustainable forestry management practices. To meet this challenge it is necessary to use certified forests (Blanco et al. 2004). Recycling of the cellulosic fibers has also been difficult due to collection, contamination, and lack of awareness among users based on their country of origin (Ervasti et al. 2016). Therefore, it is important to consider alternative fiber sources to meet a possible shortfalls in sustainably produced wood fiber. However, $89 \%$ of world paper production is based on wood, and only about $11 \%$ is based on nonwoody plants (Shatalov and Pereira 2006; Danielewicz and Surma-ślusarska 2011; Edyta et al. 2015; Cherney and Small 2016). 
Hemp has emerged recently as a viable option to address the aforementioned criteria, especially with respect to the growing demand for economic and sustainable paper products in response to an environmentally conscious populace (Choi et al. 2018; Johnson n.d.). Up until the end of the twentieth century, approximately $75 \%$ to $90 \%$ of all worldwide paper production came from hemp fiber processing until the shortage of rags threatened the monopoly of hemp and flax usage (Conard 1994; Bowyer 2001; Barnard 2015). Currently, only approximately $5 \%$ of the global paper supply is made from annual plants such as hemp (FAO 1996; Edyta et al. 2015; Johnson 2018). Hemp pulps are generally blended with wood pulps for paper production. However, there is no current known large production of $100 \%$ hemp-based paper, and little precedent demonstrating the use of hemp for paper production (Choi et al. 2018; Johnson n.d.).

Hemp has been an important crop throughout human history for food, fiber, and medicine. Despite significant progress made by the international research community, the basic biology of hemp plants remains insufficiently understood (Schluttenhofer and Yuan 2017). Worldwide, hemp is classified under the binomial nomenclature of Cannabis sativa, which therefore is analogous to a well-known source of higher tetrahydrocannabinols (THC) variants (psychoactive substances). Hemp contains $<0.3 \%$ of THC content (psychoactive substances), which make them unsuitable as narcotics, but potentially useful for a myriad of other applications (Edyta et al. 2015; Fike 2016). The hemp stems are composed of $20 \%$ fibers, which are among the strongest natural fibers in the world (Lower 1937; Andre et al. 2016; Desai and Kant 2016). The hemp stem consists of an outer ring of more valuable long phloem fibers ("bast") and an inner core of less valuable short xylem ("wood") fibers (Small et al. 2003; Cherney and Small 2016). The inner core of short xylem fibers along with stem pith are called hemp hurds. The separation of hurds from fibers can be accomplished either by using a traditional process termed "retting," involving various methods for selectively removing the pectic binding substances, or by using a modern decortication process, resulting in approximately three tons of bast fibers and seven tons of hurds per hectare. The bast fibers are the long fibers that are preferable for composites, textiles, and specialty papers (Balaji et al. 2015; Musio et al. 2018). In contrast, the hurd fibers are the low value byproduct primarily used for animal bedding and hemp-lime construction applications. However, the valorization of the utilization of hurds is possible for high value applications, such as tissue paper, cellulosic plastic composites, and building materials, such as fiberboard, to ultimately create greater economic opportunities for rural communities.

Industrial hemp is composed of $50 \%$ to $77 \%$ cellulose (Edyta et al. 2015; Crop 2018). Statistically, hemp contains three times the amount of cellulose of wood and other agricultural wastes; thus, from one hectare of hemp, a quadruple amount of paper can be produced versus one hectare of forest (Edyta et al. 2015). Moreover, hemp can be reharvested after only 4 months of cultivation. In contrast, trees involve 8 to 12 years for hardwoods such as eucalyptus and 20 to 80 years for softwoods such as pines, Douglas fir, spruce, etc., in rotation cycles (Food and Agriculture Report, 1980). Hemp paper can be bleached with oxygen delignification efficiently due to its chemical composition and morphology (Danielewicz and Surma-Ślusarska 2010) and in general, it requires fewer harsh chemicals for processing. The core fibers of hemp hurds are also easy to penetrate due to the fineness of the raw material compared to hardwood chips. Sodium carbonate $\left(\mathrm{Na}_{2} \mathrm{CO}_{3}\right)$-based cooking, a weak alkaline treatment for defibration/pulping, can be applied to hemp pulp, but it has limited use in liberating fibers from woody sources. 
For woody sources (hardwood or softwood), kraft pulping (or sulfate pulping) is the most widely used chemical pulping process. Kraft pulping uses harsh chemicals including sodium hydroxide and sodium sulfide (white liquor) to promote lignin dissolution and consequent fiber liberation (Santos et al. 2013). During fiber liberation, lignin, which acts as a glue between various fiber cells, is fragmented into smaller units, whereas carbohydrates (viz., cellulose and hemicellulose) are stepwise-hydrolyzed by polymer end reactions known as peeling (Lusby and Mass 1937; De Groot et al. 2009). However, autohydrolysis, in conjunction with enzymes, has proven to be an efficient process for the defibration of fibers from hemp (Barta et al. 2010; Gandolfi et al. 2013) without the associated drawbacks of kraft pulping cited above. Autohydrolysis employs water at a high temperature and pressure to cleave the acetyl groups in hemicellulose that bind lignin to the cell wall matrix. During this reaction, acetic acid is liberated as a side product, which catalyzes the reaction and help in the liberation of cellulose (Barta et al. 2010).

The hypothesis driving the current work is that by controlling the temperature and conditions for autohydrolysis, efficient defibration in hemp will occur to provide fibers that can be used to produce tissue paper having favorable properties. As the autohydrolysis (also referred as hydrothermal or hot water) process does not require any strong chemical treatments, hemp paper contributes to sustainability efforts that reduce deforestation and boost the economy of local producers and local businesses consuming paper products. In addition, the impact of the addition of hemp fibers into kraft pulped hardwood fibers was also evaluated for tissue and towel paper properties. The principal objective of this study was to avail the scientific and industrial communities of a future industrial hemp-based bioeconomy for biochemicals and bioproducts.

\section{EXPERIMENTAL}

\section{Materials}

The dew retted and decorticated Futura 75 cultivar hemp hurds were procured from the Netherlands. The obtained hemp hurds were further passed through a $9.5 \mathrm{~mm}$ slot size screen to remove fines. The final hurds were 4 to $6 \mathrm{~mm}$ in width and 15 to $30 \mathrm{~mm}$ in length, while mixed hardwood chips were obtained from WestRock mill, Evadale, TX. Cellulose, lignin, ash, and extractive contents in hemp hurds were determined according to the laboratory analytical procedure (LAP) (NREL/TP-510-42618) or the ASTM E1758-01 (2015) standard. The estimation of acid insoluble lignin, ash, and extractives were completed according to TAPPI T222 om-11 (2011) standard and the LAP-010 as per ASTM E1690-08 (2016) standard methods, respectively.

\section{Methods}

\section{Defibration/pulping process}

The laboratory defibration scheme, highlighting the features of the autohydrolysis and sodium carbonate defibration processes, is shown in Fig. 1. A higher water to solids ratio of 8:1 was used for hemp due to its low bulk density compared to hardwood. The autohydrolysis, as well as the carbonate hydrolysis with $4 \%$ sodium carbonate $\left(\right.$ as $\left.\mathrm{Na}_{2} \mathrm{O}\right)$, and $12 \%$ active alkali to achieve $25 \%$ sulfidity $\left(\mathrm{NaOH}+\mathrm{Na}_{2} \mathrm{~S}\right)\left(\mathrm{as} \mathrm{Na}_{2} \mathrm{O}\right)$ in kraft pulping, were conducted in a stainless-steel reactor under a controlled temperature $\left(160{ }^{\circ} \mathrm{C}\right)$ for $3 \mathrm{~h}$ using water or a mild concentration of sodium carbonate $\left(\mathrm{Na}_{2} \mathrm{CO}_{3}\right)$ and a high 
concentration of alkali charge (kraft), respectively. The pulp was washed by tap water and refined using a laboratory disc refiner (Model 148-2, rpm 3600; The Bauer Bros. Co., Springfield, OH, USA) at disc gaps of $0.2 \mathrm{~mm}$ to $0.1 \mathrm{~mm}$ to $0.05 \mathrm{~mm}$ with three passes for hardwood pulp and disc gaps of $0.1 \mathrm{~mm}$ to $0.05 \mathrm{~mm}$ with two passes for hemp pulp before screening on a $0.15-\mathrm{mm}$ slotted laboratory screen. The screened pulp yield, Kappa number, and freeness were determined using the TAPPI T236 om-99 (2006) and TAPPI T227 om99 (1999) standard methods, respectively. The fiber length $\left(l_{\mathrm{w}}-\right.$ length-weighted, $l_{\mathrm{n}}-$ arithmetic mean length), and fines content of hemp and hardwood pulps were obtained with the fiber quality analyzer (FQA-360; OpTest Equipment Inc., Hawkesbury, ON, Canada).

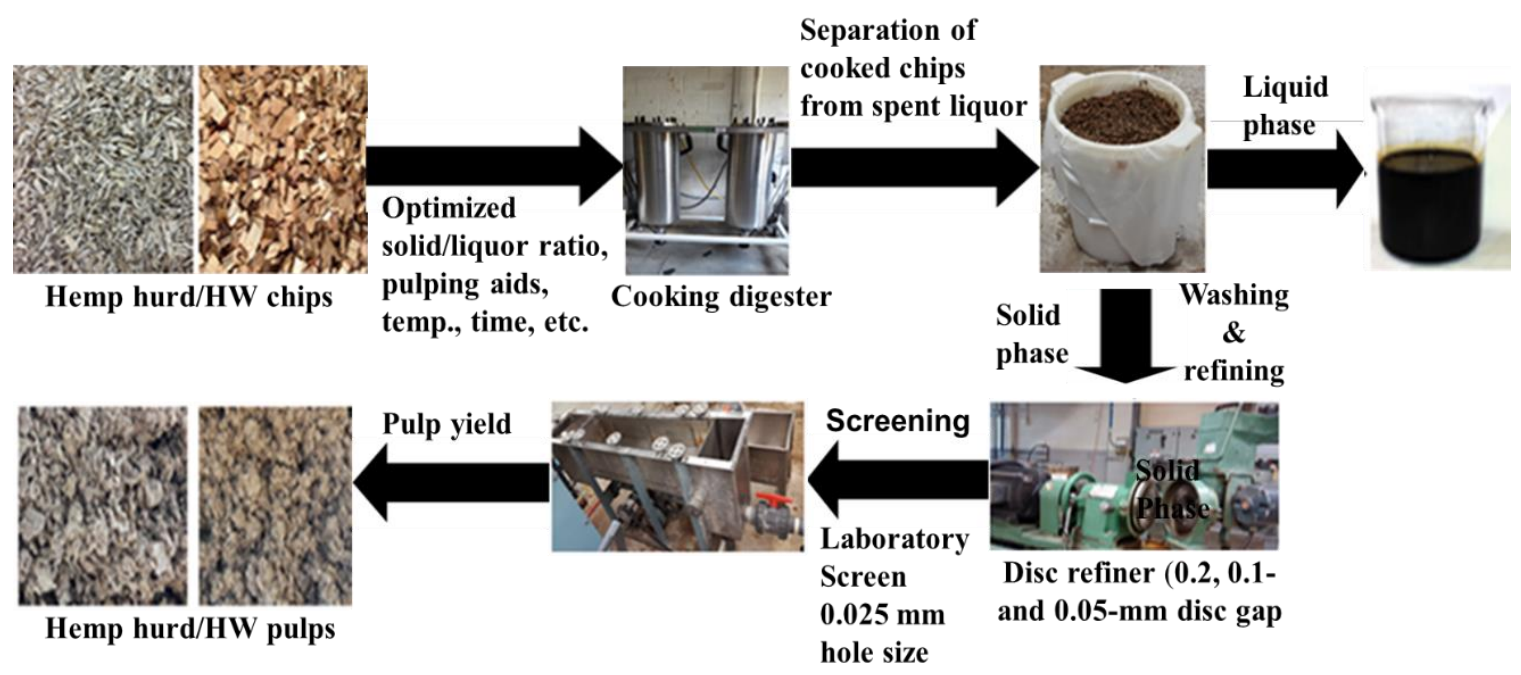

Fig. 1. Pulping Schematic for the Hemp Hurds and Subsequent Processing of Fibers

\section{Handsheets preparation}

Tissue handsheets at a basis weight of $30 \mathrm{~g} / \mathrm{m}^{2}$ were prepared according to TAPPI T205 sp-02 (2006) method with the following modifications: a light weight $(\sim 0.15 \mathrm{~kg})$ foam roller was used for couching instead of a standard heavy $(13 \mathrm{~kg})$ brass roller and did not include the pressing process. All handsheets were conditioned at $23{ }^{\circ} \mathrm{C}$ and $50 \%$ relative humidity $(\mathrm{RH})$ before testing.

\section{Handsheets characterization}

The structural and chemical characterizations of the obtained tissue handsheets were completed using a FEI Verios 460L field emission scanning electron microscope (FEI Verios 460L; Thermo Scientific, Waltham, MA, USA) at an accelerating voltage of $5 \mathrm{kV}$ and 13 pA current. The time-of-flight-secondary ion mass spectrometry (ToF-SIMS) analysis (Ion-Tof USA Inc, Chestnut Ridge, NY, USA ) with negative ions was performed for the area $500 \mu \mathrm{m} \times 500 \mu \mathrm{m}$ to show the lignin distribution over cellulosic fibers. The tissue handsheets were also tested for standard tissue properties, such as water absorption using the ISO 12625-8:2010(E) (2010) method, density according to TAPPI T258 om-02 (2006), air resistance/porosity as per TAPPI T460 om-02 (2006), as well as strength properties, such as dry and wet tensile strengths, employing TAPPI T494 om-01 (2006) and TAPPI T456 om-03 (2003) methods, respectively. Ball burst and softness were tested using the Emtec TSA softness tester (TSA; Emtec Electronic GmbH, Leipzig, Germany). 


\section{RESULTS AND DISCUSSION}

\section{Chemical Composition}

Table 1 indicates the chemical compositions of hemp hurds and hardwood. The lignin and ash contents of hemp hurds were found to be slightly higher than angiosperms (hardwoods). However, the extractive content in hemp hurds was considerably lower. Cellulose content was $42 \%$, which is consistent with earlier studies (Gümüşkaya et al. 2007; Stevulova et al. 2014), although much less than ( 75\%) bast fibers (Crônier et al. 2005).

Table 1. Chemical Compositions of Hemp and Hardwood

\begin{tabular}{|c|c|c|c|c|c|}
\hline Raw Material & $\begin{array}{l}\text { Cellulose } \\
(\%)\end{array}$ & $\begin{array}{l}\text { Lignin } \\
(\%)\end{array}$ & $\begin{array}{l}\text { Extractives } \\
(\%)\end{array}$ & Ash (\%) & $\begin{array}{c}\text { Hemicelluloses and Pectin } \\
(\%)\end{array}$ \\
\hline Hemp hurds & 42.0 & 27.4 & 2.2 & 1.4 & 27.0 \\
\hline Hardwood & 44.2 & 26.9 & 3.7 & 1.1 & $23.7^{2}$ \\
\hline
\end{tabular}

\section{Pulp Yield}

Pulp yield was mainly controlled by the intensity of defibrationtpulping processes (autohydrolysis vs. carbonate $v s$. kraft pulp process). The pulp yields (total pulp wt $\%$ obtained after defibration) are given in Table 2 . The $\mathrm{pH}$ change in the spent cooking liquor from defibration represented the alkali consumed during defibration to neutralize wood acids, remove lignin, and separate fibers. At a higher $\mathrm{pH}$, the defibration rate was higher; thus, the lignin level was lower compared to autohydrolysis. The bulk defibration rate was nearly proportional to -OH concentration (Lusby and Mass 1937; Gierer and Forest 1980). The yield of hemp pulp was higher compared to hardwood pulp from both carbonate and kraft pulping processes. The addition of even $25 \%$ of hemp fibers can enhance the overall yield by $\sim 4 \%$ when added to hardwood pulp obtained from the high yield kraft process.

Table 2. Hemp and Hardwood Fibers and Residual Chemicals

\begin{tabular}{|c|c|c|c|c|c|c|}
\hline $\begin{array}{l}\text { Defibrating } \\
\text { Process }\end{array}$ & Definition & $\begin{array}{c}\text { Initial Liquor } \\
\mathrm{pH}\end{array}$ & $\begin{array}{c}\text { Spent } \\
\text { Liquor pH }\end{array}$ & $\begin{array}{l}\text { Freeness } \\
\text { CSF }\end{array}$ & $\begin{array}{l}\text { Total } \\
\text { Yield } \\
(\%)^{1}\end{array}$ & $\begin{array}{c}\text { Klason } \\
\text { Lignin } \\
(\%)\end{array}$ \\
\hline Hemp/A & Auto hydrolyzed & 7.0 & 3.7 & 700 & 73.0 & 23.5 \\
\hline Hemp/C & Hemp-4\%carbonate & 11.2 & 6.0 & 478 & 71.3 & 22.1 \\
\hline Hemp/K & Hemp-high yield Kraft & 12.8 & 9.4 & 402 & 59.3 & 14.5 \\
\hline $\mathrm{HW} / \mathrm{C}$ & $\begin{array}{l}\text { Hardwood- } \\
4 \% \text { carbonate }\end{array}$ & 11.3 & 6.3 & 705 & 70.3 & 21.3 \\
\hline $\mathrm{HW} / \mathrm{K}$ & $\begin{array}{l}\text { Hardwood-high yield } \\
\text { Kraft }\end{array}$ & 13.3 & 12.4 & 607 & 56.8 & 8.6 \\
\hline $\begin{array}{l}\mathrm{HW} / \mathrm{K}- \\
\mathrm{Hemp} / \mathrm{A}\end{array}$ & $\begin{array}{l}75 \% \mathrm{HW} / \mathrm{K}+ \\
25 \% \mathrm{Hemp} / \mathrm{A}\end{array}$ & $\mathrm{N} / \mathrm{A}$ & $\mathrm{N} / \mathrm{A}$ & 620 & $60.8^{*}$ & $\mathrm{~N} / \mathrm{A}$ \\
\hline $\begin{array}{l}\mathrm{HW} / \mathrm{K}- \\
\mathrm{Hemp} / \mathrm{C}\end{array}$ & $\begin{array}{l}75 \% \mathrm{HW} / \mathrm{K}+ \\
25 \% \mathrm{Hemp} / \mathrm{C}\end{array}$ & $\mathrm{N} / \mathrm{A}$ & $\mathrm{N} / \mathrm{A}$ & 490 & $60.4^{*}$ & $\mathrm{~N} / \mathrm{A}$ \\
\hline
\end{tabular}




\section{Morphology of Hemp Hurds Fibers}

The fiber length $\left(l_{\mathrm{w}}-\right.$ length weighted, $l_{\mathrm{n}}$ - arithmetic mean length), and fines content of hemp and hardwood pulps were obtained with the FQA are shown in Table 3. For papermaking materials, particles that pass through a $75-\mu \mathrm{m}$ diameter circular hole or a 200-mesh screen of a fiber length classifier are regarded as fines (Fischer et al. 2017). Hemp pulps can be classified as short-length fibers, which means the length is less than 1.0 $\mathrm{mm}$. The length of hardwood fibers was comparatively longer $(\sim 1 \mathrm{~mm})$. The hemp autohydrolysis produced the highest fines content and resulted in shorter fiber length compared to carbonate hydrolysis and kraft pulping. This can be correlated to the $\mathrm{pH}$ used for pulping and is in line with earlier studies that demonstrated that higher $\mathrm{pH}$ results in lower fine generation and increased fiber length (Jansson 2015). Surprisingly, the fines content of the hardwood kraft pulp was higher than the hemp kraft pulp.

Table 3. Fiber Quality Analysis

\begin{tabular}{|c|c|c|c|}
\hline Defibration Process & Fiber Length $(\mathrm{w})(\mathrm{mm})$ & Fines $(\mathrm{w})(\%)$ & Mean Width $(\mu \mathrm{m})$ \\
\hline Hemp/A & $0.527 \pm 0.005$ & $15.86 \pm 0.93$ & $26.8 \pm 0.64$ \\
\hline Hemp/C & $0.714 \pm 0.006$ & $7.06 \pm 0.06$ & $25.1 \pm 0.35$ \\
\hline Hemp/K & $0.688 \pm 0.004$ & $6.71 \pm 0.14$ & $24.2 \pm 0.28$ \\
\hline $\mathrm{HW} / \mathrm{C}$ & $1.269 \pm 0.001$ & $5.81 \pm 0.03$ & $20.9 \pm 0.21$ \\
\hline $\mathrm{HW} / \mathrm{K}$ & $1.099 \pm 0.004$ & $15.19 \pm 0.27$ & $19.4 \pm 0.57$ \\
\hline $\mathrm{HW} / \mathrm{K}-\mathrm{hemp} / \mathrm{A}$ & $1.025 \pm 0.007$ & $12.23 \pm 0.33$ & $19.7 \pm 0.28$ \\
\hline $\mathrm{HW} / \mathrm{K}-\mathrm{hemp} / \mathrm{C}$ & $1.071 \pm 0.014$ & $11.97 \pm 0.33$ & $19.8 \pm 0.21$ \\
\hline
\end{tabular}

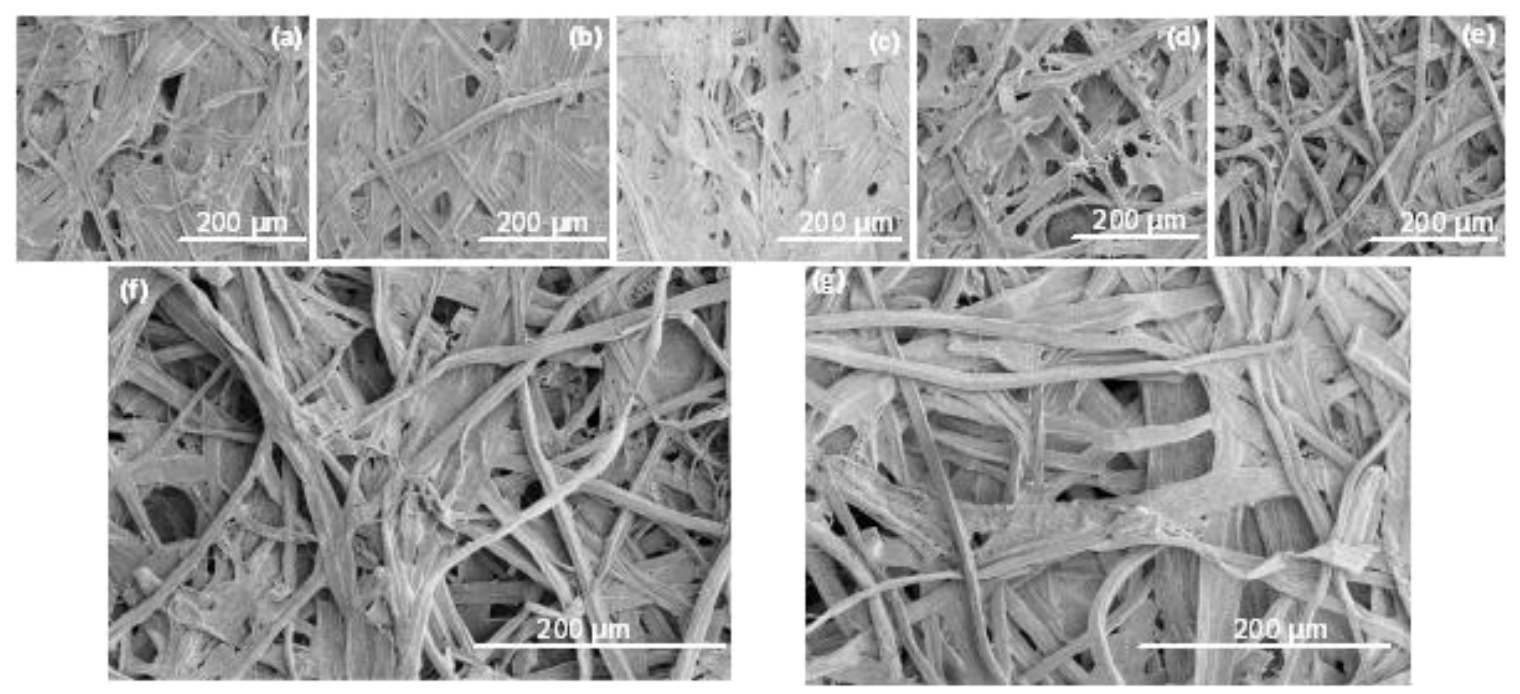

Fig. 2. SEM pictures (250x magnification) of (a) Hemp/A; (b) Hemp/C; (c) Hemp/K; (d) HW/C; (e) $\mathrm{HW} / \mathrm{K}$; (f) HW/K-Hemp/A; and (g) HW/K-Hemp/C

The SEM microphotographs show an incrementally denser network for Hemp/A, Hemp/C, and Hemp/K tissue handsheets because of more flattened hemp fibers (Fig. 2a, $2 \mathrm{~b}$, and $2 \mathrm{c}$ ). This suggests a potential higher degree of desirable defibration, especially for Hemp/C and Hemp/K, causing fiber flattening due to mechanical (disc) refining, as can be seen with low CSF freeness numbers in Fig. 4. The Hemp/A fibers showed lesser defibration than Hemp/C and Hemp/K. However, Hemp/C fibers showed more similar surface characteristics comparable to HW/C fibers (Fig. 2b and 2d). The HW/K pulp showed the least density and a more porous consolidation of fibers in the handsheets, which 
was reflected later in air resistance and water absorption results. The addition of Hemp/A in $\mathrm{HW} / \mathrm{K}$ did not affect the morphology or geometry of the handsheet relative to density and apparent porosity (Fig. 2f). However, the HW/K-Hemp/C (Fig. 2g) showed a slight decrease in the density and porosity of the handsheet when compared to a HW/K tissue handsheet. Carbonate treatment affected the final state of hemp fiber bundles by providing higher defibration. This might be due to increased swelling of hemp fibers in the presence of carbonate ions, resulting in more defibration and a denser sheet (Jansson 2015).
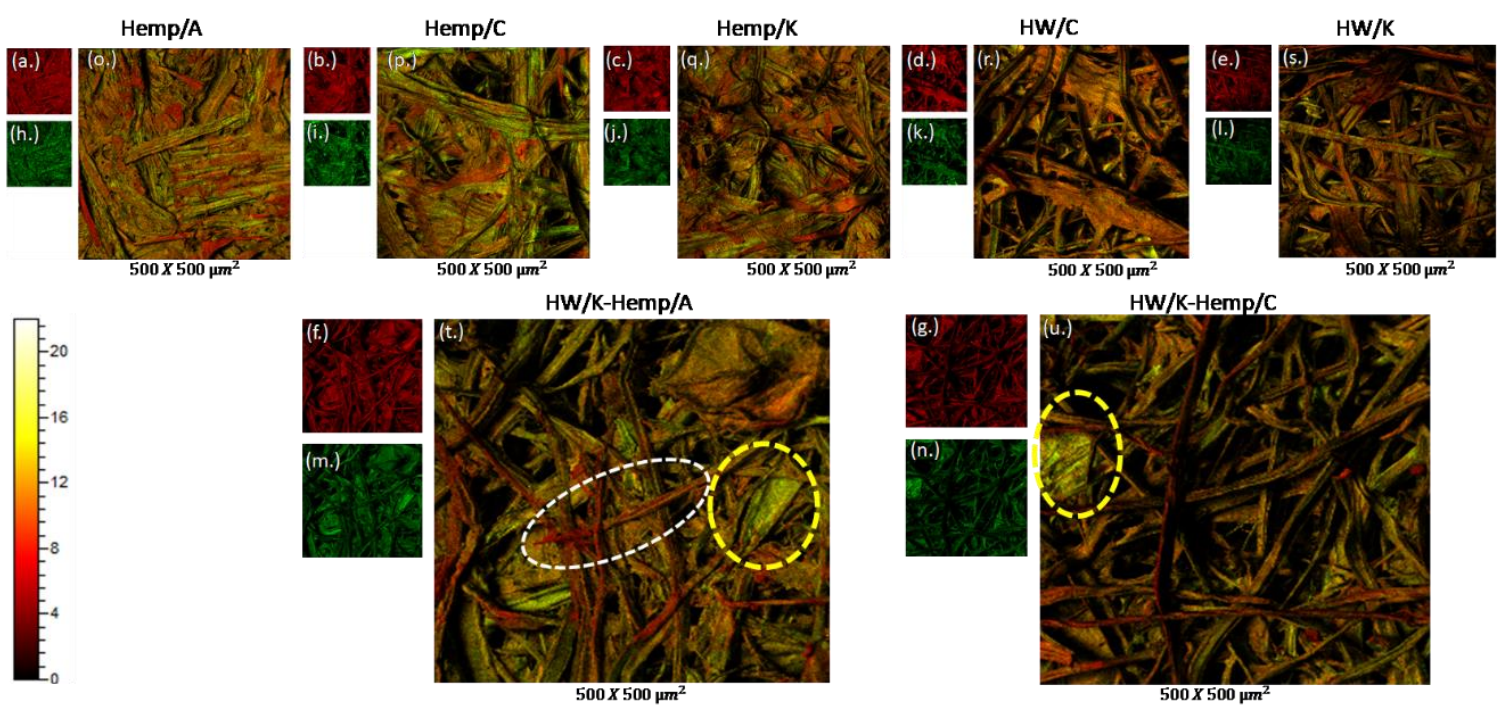

$\mathrm{HW} / \mathrm{K}$-Hemp/C

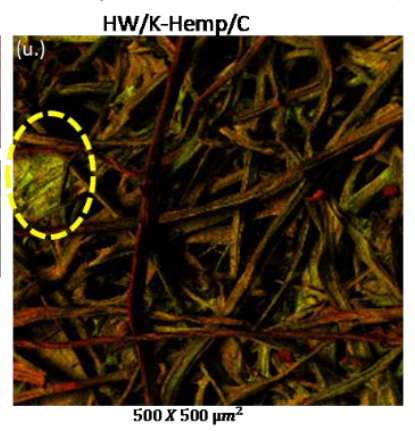

Fig. 3. The ToF-SIMS images of hardwood and various processed hemp fibers corresponding to total cumulative surface (a), (b), (c), (d), (e), (f), and (g); Sum of guaiacyl (G) and syringyl (S) $\left(\mathrm{C}_{8} \mathrm{H}_{9} \mathrm{O}_{2+}, \mathrm{C}_{8} \mathrm{H}_{7} \mathrm{O}_{3+}, \mathrm{C}_{9} \mathrm{H}_{11} \mathrm{O}_{3+}, \mathrm{C}_{9} \mathrm{H}_{9} \mathrm{O}_{4+}\right)$ lignin fragments (h), (i), (j), (k), (l), (m), (n); and overlay of $\mathrm{G}$ and $\mathrm{S}$ characterized fragments on total cumulative surface $(\mathrm{o}),(\mathrm{p}),(\mathrm{q}),(\mathrm{r}),(\mathrm{s}),(\mathrm{t})$, and $(\mathrm{u})$

Figure 3 (ToF-SIMS) illustrates the chemical component distribution of lignin in the fibers from hardwood and hemp samples. The color bar at bottom left corner of Fig. 3 depicts the intensity of presence of scattered positive ion lignin fragment. The lighter the color (at higher value of intensity), the more lignin ion fragments were present. Dark/black color at the bottom of the scale bar depicts the absence of lignin fragments in the ToFSIMS images. Figure 3a, 3b, 3c, 3d, 3e, 3f, and 3g present the total cumulative surface inclusive of all chemical fragments generated during the ion-mediated surface interrogation by ToF-SIMS. Figure 3h, 3i, 3j, 3k, 31, 3m, and 3n depict the distributions of guaiacyl (G) $\left(\mathrm{C}_{8} \mathrm{H}_{9} \mathrm{O}_{2}{ }^{+}, \mathrm{C}_{8} \mathrm{H}_{7} \mathrm{O}_{3}{ }^{+}\right)$and syringyl $(\mathrm{S})\left(\mathrm{C}_{9} \mathrm{H}_{11} \mathrm{O}_{3}{ }^{+}, \mathrm{C}_{9} \mathrm{H}_{9} \mathrm{O}_{4}{ }^{+}\right)$lignin monomers using respective generated fragments. For example, the more greenish and yellowish color in Figs. $3 o$ and $3 p$ represents more lignin present on the surface compared to Figs. 3q, 3r and 3s. Figures 3o, 3p, 3q, 3r, 3s, 3t, and 3u show the overlay of lignin fragments over the total cumulative surface, and presents how the lignin is distributed on the paper surface. The green patches correspond to lignin in the overlay graph illustrating its fiber surface distribution.

It should be noted that tissue handsheets from hardwood ( $\mathrm{HW} / \mathrm{C}$ and $\mathrm{HW} / \mathrm{K})$ and Hemp/K fibers showed a sparse distribution of surface lignin (attenuated green color). The Hemp/A fibers showed a lower distribution of lignin (less green color in overlay graph) on the surface compared to Hemp/C fibers, irrespective of the fact that carbonate-treated fibers had a lower lignin concentration than Hemp/A (Table 3). Overlaid micrographs of G and 
S lignin monomers over total cumulative chemically characterized surface showed that lignin was not uniformly distributed on the hemp fibers. In hardwood fibers, the lignin is distributed more uniformly although in lower amounts, as expected. Thus, it may be safely concluded that lignin was more present in the bulk of the fiber for Hemp/A fibers, allowing for more open surfaces for the cellulosic and hemicellulosic components to engage in enhanced fiber-fiber interactions and hence, consolidation. In HW/K-Hemp/A and HW/KHemp/C handsheets, the distribution of hemp (yellow circle) and hardwood (white circle) fibers can be distinguished easily based on lignin distribution and the geometry of fibers (Fig. 3t and 3u). For instance, green colored (more surface lignin) and flattened structures were characterized as hemp fibers. However, more reddish (less surface lignin) and elongated structures were easily characterized as HW/K fibers.

\section{Water Absorption}

Water absorption is one of the key characteristics of tissue paper. Water can be absorbed through the porous structure of paper or can be taken up by capillary action through the cell cavities and fiber walls of the cellulosic fibers (Bristow 1971; Schuchardtl and Berg 1991). The capacity of water absorption depends on several factors such as paper density, pulp freeness, fiber types, fiber surface, and chemicals used in the paper making process, as well as aspects of the creping process. The freeness of pulp is the measure of the rate at which a dilute suspension of pulp may be drained. The freeness, or drainage rate has been shown to be related to the surface conditions and swelling of the fibers. The freeness of the Hemp/C and Hemp/K pulp samples was lower relative to Hemp/A, HW/C, and HW/K pulp samples (Table 3 ). This can be best explained on the basis of flattened, more consolidated hemp fibers (Fig. 2) and a higher swellability of fibers at higher $\mathrm{pH}$, which is known to provide a better refining process that is able to lower freeness (Choi et al. 2016). As expected, the freeness of mixed HW/K-Hemp/A and HW/K-Hemp/C pulps were reduced slightly, based on networking of fibers shown in Fig. 2.

\section{$\square$ Water Absorption (g/g) aCSF Freeness}

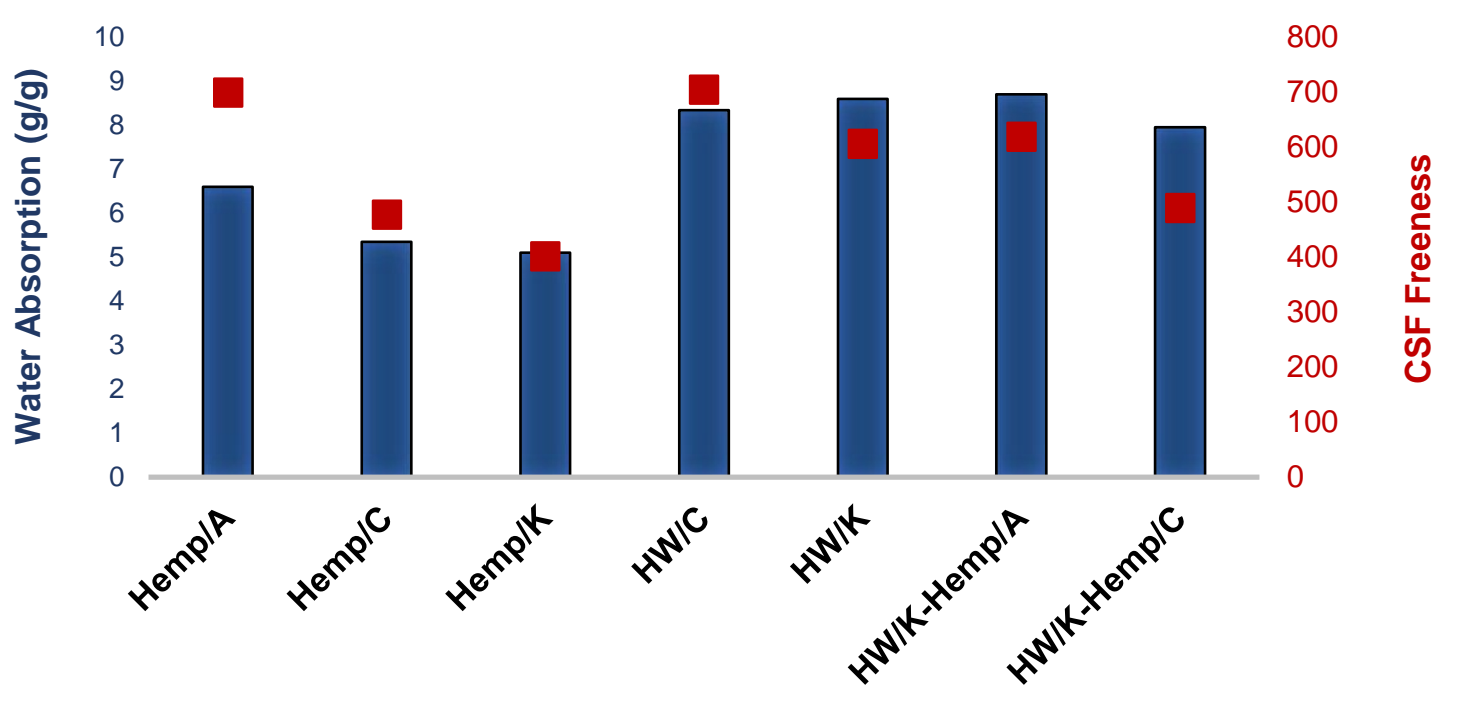

Fig. 4. Freeness and water absorption of tissue handsheets 
Figure 4 shows the water absorption of tissue handsheets made from hemp and hardwood pulps. For hemp pulp, water absorption decreased with decreasing freeness. The $\mathrm{HW} / \mathrm{C}$ and $\mathrm{HW} / \mathrm{K}$ tissue handsheets showed about $40 \%$ higher water absorption compared to Hemp/C and Hemp/K tissue handsheets. This confirmed that more bulky and porous structures indicate better water absorption (Fig. 2) (González et al. 2012).

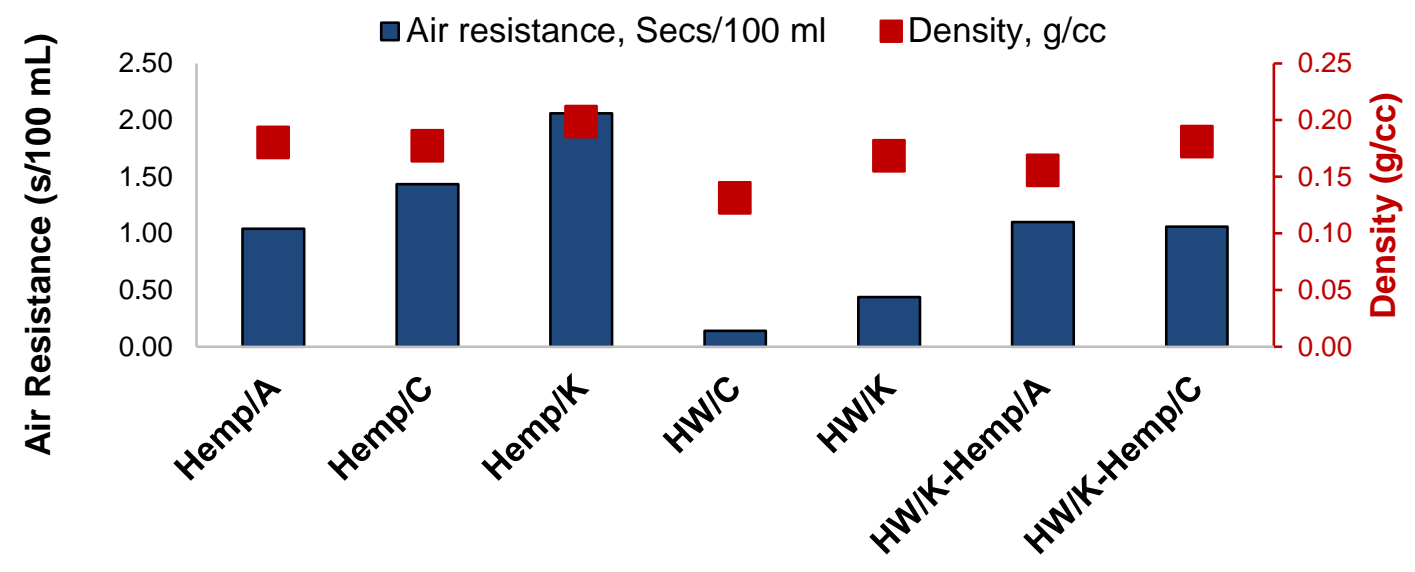

Fig. 5. Apparent density and air resistance of tissue handsheets

When comparing the water absorption data with ToF-SIMS images (Fig. 3), it was concluded that a higher amount of surface lignin $(\mathrm{Hemp} / \mathrm{C})$ resulted in lower water absorption. The water absorption of hardwood pulp handsheets was the highest at the lowest density and highest porosity (lowest air resistance) (Figs. 4 and 5). However, addition of $25 \%$ of Hemp/A and Hemp/C in HW/K (HW/K-Hemp/A and HW/K-Hemp/C, respectively) did not affect the density of the handsheets considerably but slightly improved the air resistance compared to $\mathrm{HW} / \mathrm{K}$ handsheets. Water absorption was also found unaffected after addition of Hemp/A and Hemp/C fibers in HW/K. This confirmed the information in the SEM images shown in Fig. 2.

\section{Mechanical Strength}

The most common strength tests for tissue paper are dry tensile, wet tensile, and the ball burst test, which are important for both manufacturers and end use. Tensile strength depends on factors such as fiber strength, fiber length, and bonding. Wet tensile strength is tensile strength in a wet state. In this study, dry and wet strengths showed similar behavior for both hemp and hardwood fibers (Fig. 6). The handsheets from Hemp/A and HW/C showed the lowest dry tensile strength. The Hemp/C and Hemp/K tissue handsheets showed higher tensile strengths compared to HW/C and HW/K tissue handsheets, which is related to the flattened morphology of hemp fibers resulting in more bonding between fibers compared to cylindrical hardwood fibers (Johansson 2011; Jani et al. 2016). Overall, the addition of $25 \% \mathrm{Hemp} / \mathrm{A}$ and Hemp/C in $\mathrm{HW} / \mathrm{K}$ resulted in an increase in wet tensile and dry tensile strengths of $16 \%$ and $7 \%$, respectively (Fig. 6).

Resistance to mechanical penetration through a tissue paper is called ball burst resistance/strength, an important characteristic of tissue paper. A tissue paper should possess sufficient ball burst strength to effectively endow tissue paper with desirable end user properties. Low dry burst strength can cause problems in the manufacturing and converting processes. Similar to tensile strength results, the ball burst resistance of Hemp/K 
and Hemp/C was highest in tissue handsheets under specified conditions (Fig. 7). The Hemp/A and HW/C showed the lowest burst resistance, which was related to the lower defibration of fibers and consequently lowest interfiber bonding. Similar to tensile index, burst resistances of $\mathrm{HW} / \mathrm{K}-\mathrm{Hemp} / \mathrm{A}$ and $\mathrm{HW} / \mathrm{K}-\mathrm{Hemp} / \mathrm{C}$ were increased compared to solely $\mathrm{HW} / \mathrm{K}$ tissue handsheets, demonstrating a synergistic effect between hardwood and hemp fibers.

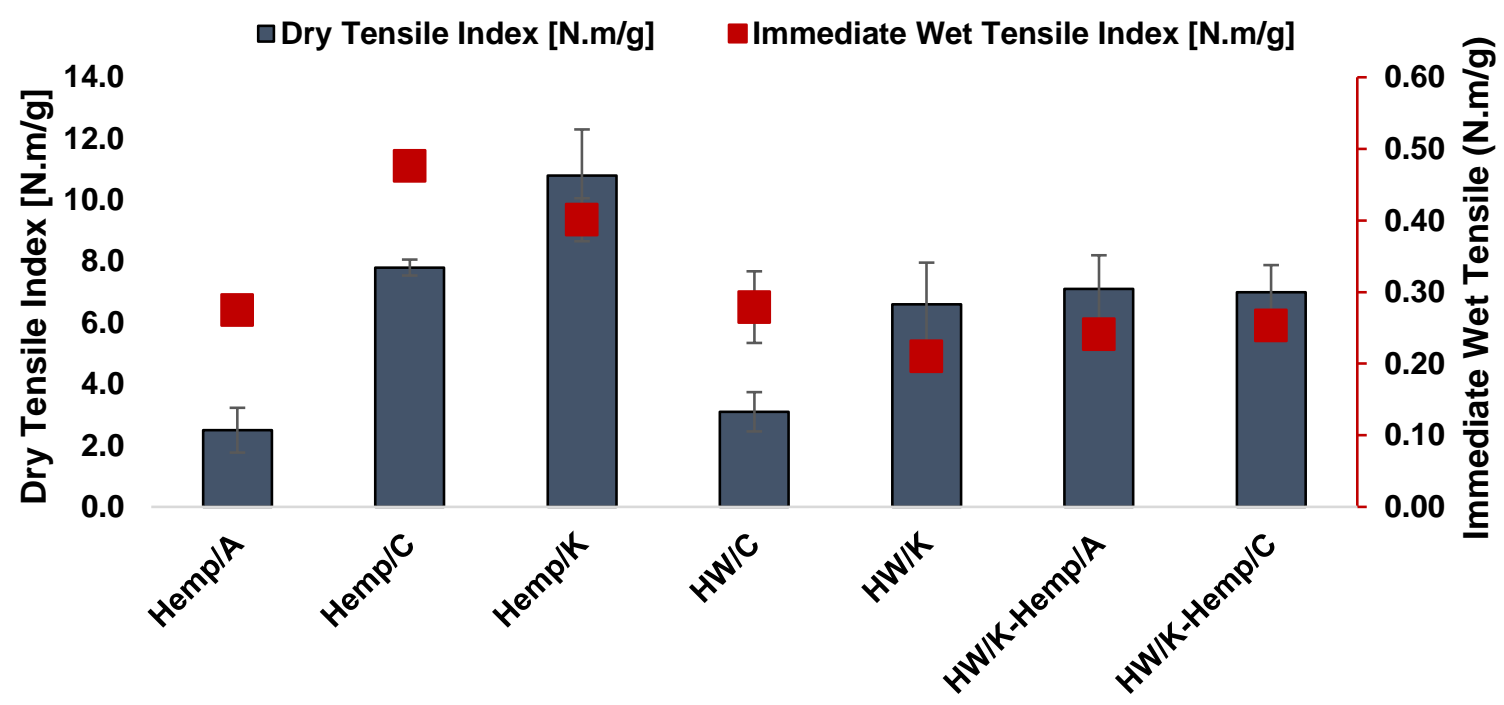

Fig. 6. Dry and wet (immediate) tensile strength of tissue handsheets

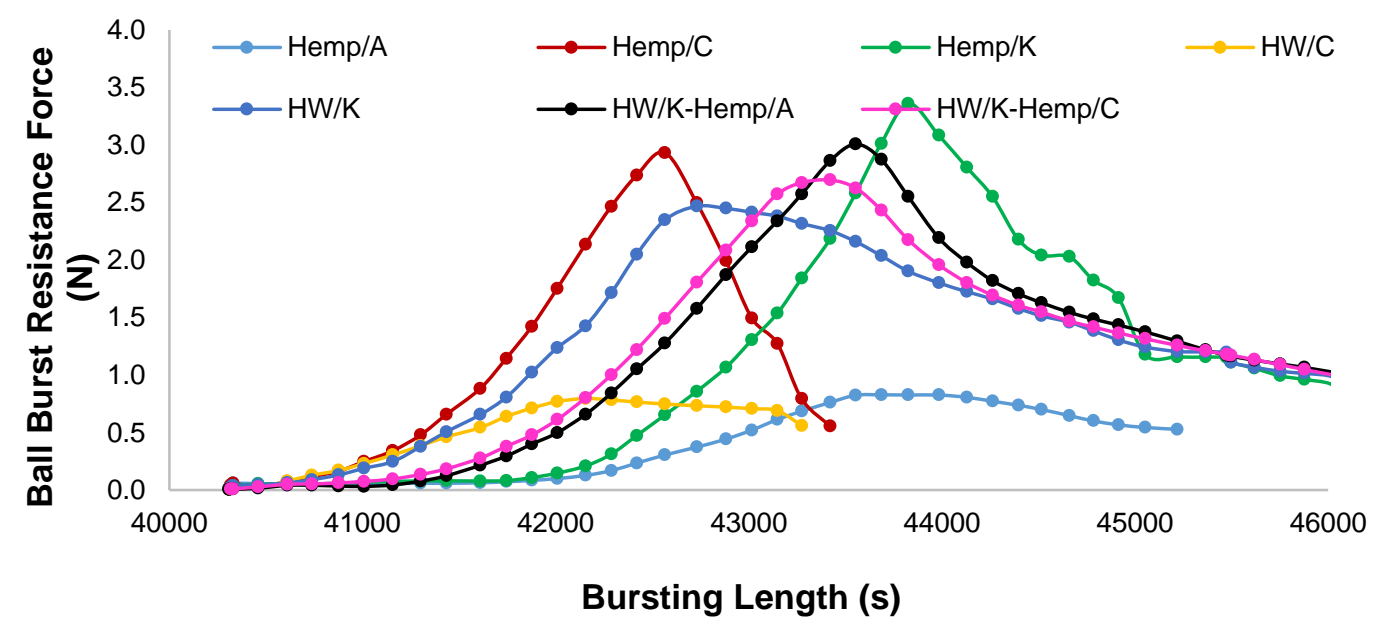

Fig. 7. Ball burst resistance force vs. bursting length of tissue handsheets

\section{Softness}

An additional important characteristic for tissue papers and napkins is softness. Figure 8 shows the softness of tissue paper as relayed by the Emtec TSA method. The softness of tissue paper is a combination of bulk and surface smoothness (Grossman 1977). Softness decreases with increasing mechanical strength properties (Gigac and Fišerová 2008). For instance, to increase the strength properties of tissue handsheets, interfiber bonding must be increased, which reduces the flexibility of the paper structure. However, 
this results in lower softness (De Assis et al. 2018). The balance between softness and paper strength is delicate and can be solved by adding chemicals to the pulp or on the surface of the paper. In Fig. 8, the first dominant peak at $750 \mathrm{~Hz}$ frequency, also called the TS750 peak, indicates that the overall sheet structure can be defined as the roughness/smoothness of the paper. A higher peak (sound intensity) resulted in rougher paper and vice versa. The second dominated peak at $7000 \mathrm{~Hz}$ frequency, also known as the TS7 peak, indicates the softness of tissue paper (Shelp et al. 2017). Like smoothness, a higher intensity of the second peak resulted in the paper becoming less soft. The Hemp/C and Hemp/K tissue handsheets were observed with the least softness (Fig. 8), which was opposite to the trend of the ball burst strength as shown in Fig. 7. The HW/K-Hemp/A handsheets showed the highest softness (lowest peak at $11000 \mathrm{~Hz}$ ), which was even lower than the HW/K paper.

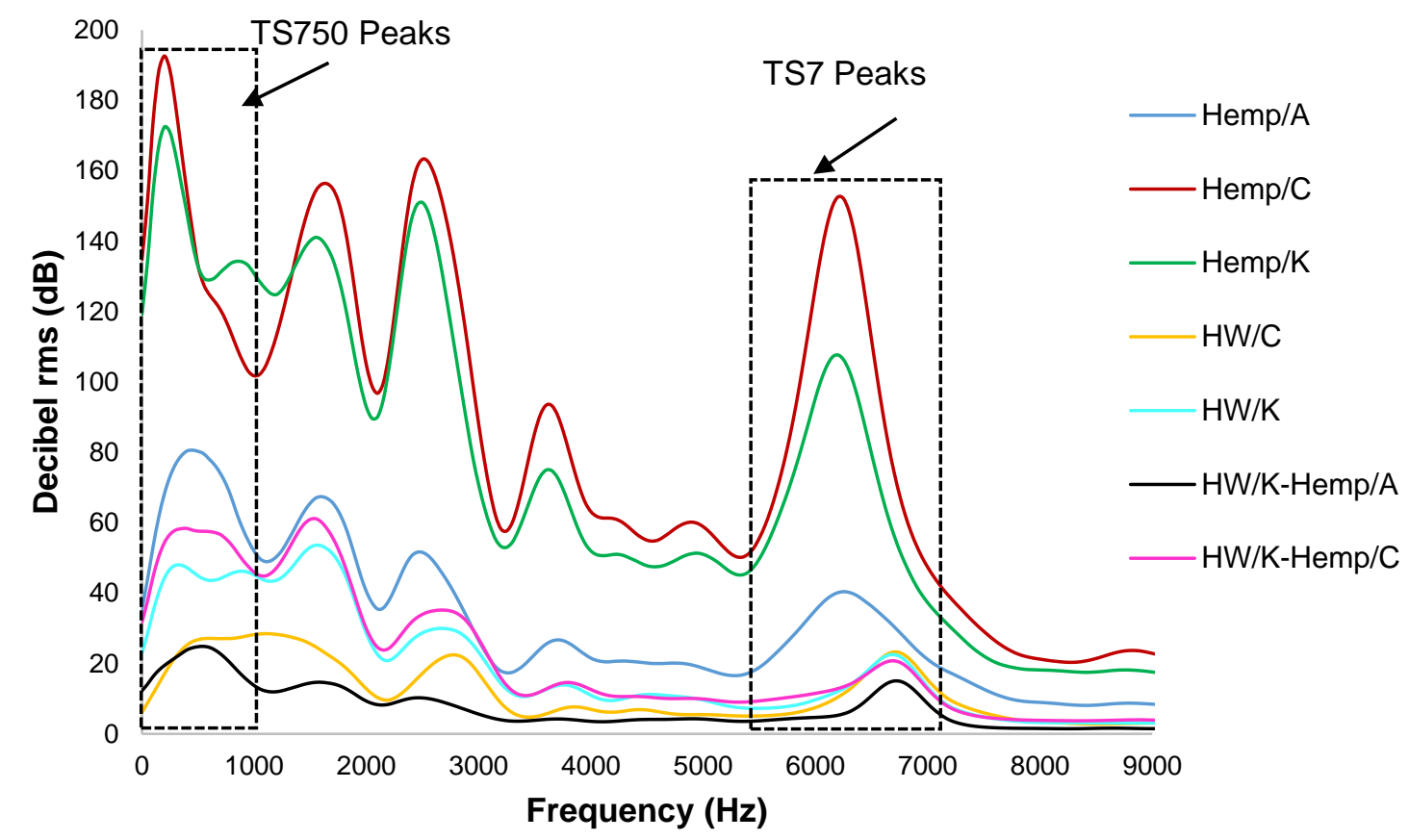

Fig. 8. TSA softness of tissue handsheets

\section{CONCLUSIONS}

1. This work has principally shown that hemp hurds can be defiberized using a chemicalfree (autohydrolysis) process and can be substituted for a portion of chemically (harsh)pulped hardwood fibers to deliver equal or better performance.

2. The yield of hemp pulp was higher compared to hardwood pulp from both carbonate and kraft pulping processes. The addition of even $25 \%$ hemp fibers enhanced the overall yield by $\sim 4 \%$ when added to hardwood pulp obtained from high yield kraft process.

3. The hemp pulp resulted in improvements in tensile index, burst resistance, and softness of tissue handsheets when compared to solely kraft hardwood pulp handsheets without adversely impacting water absorption. 
4. The chemical composition, morphology, shape, and size of hemp fibers were strongly correlated to tissue handsheets properties such as water absorption, burst resistance, softness, and wet and dry tensile strengths.

5. In total, the use of hemp hurds fibers can lead to a variety of eco-friendly tissue and towel products.

\section{ACKNOWLEDGMENTS}

The analytical aspects of this work were conducted in part at the Analytical Instrumentation Facility (AIF) at North Carolina State University, which is supported by the State of North Carolina and the National Science Foundation (award number ECCS1542015). Additionally, the authors thank Mr. Tripp Martin for his expert advice and his generous provision of the hemp used to conduct this work.

\section{REFERENCES CITED}

Andre, C. M., Hausman, J.-F., and Guerriero, G. (2016). "Cannabis sativa: The plant of the thousand and one molecules," Frontiers in Plant Science 7, Article Number 19. DOI: 10.3389/fpls.2016.00019

ASTM E1690-08 (2016). "Standard test method for determination of ethanol extractives in biomass," ASTM International, West Conshohocken, PA, USA.

ASTM E1758-01 (2015). "Standard test method for determination of carbohydrates in biomass by high performance liquid chromatography," ASTM International, West Conshohocken, PA, USA.

Barnard, D. (2015). All About the Hemp Fibers-10,000 Years of History, Hemp Inc. Stock Trading Symbol OTC Hemp, Las Vegas, NV, USA.

Barta, Z., Oliva, J. M., Ballesteros, I., Dienes, D., Ballesteros, M., and Réczey, K. (2010). "Refining hemp hurds into fermentable sugars or ethanol," Chemical \& Biochemical Engineering 24(3), 331-339.

Balaji, A., Karthikeyan, B., and Sundar Raj, C. (2015). "Bagasse fiber - The future biocomposite material: A review." International Journal of ChemTech Research 7(1), 223-233.

Blanco, A., Negro, C., Monte, C., Fuente, E., and Tijero, J. (2004). "The challenges of sustainable papermaking," ACS Environmental Science \& Technology 38(21), 414A420A. DOI: 10.1021/es040654y

Bowyer, J. L. (2001). Industrial Hemp (Cannabis sativa L.) as a Papermaking Raw Material in Minnesota: Technical, Economic, and Environmental Considerations, Department of Wood \& Paper Science, University of Minnesota, Minneapolis, MN, USA.

Bristow, A. (1971). "Swelling of paper during the sorption of aqueous liquids," Svensk Papperstidning 74(20), 645-652.

Cherney, J. H., and Small, E. (2016). "Industrial hemp in North America: Production, politics and potential," Agronomy MDPI 6(4), Article Number 58.

DOI: 10.3390/agronomy6040058

Choi, E., Dresser, S., Halliday, E., Jolibois, H., Kim, J., Leanza, P., Mason, C., Lynch, 
C., and Plenert, C. (2018). A Review of Hemp as a Sustainable Agricultural Commodity: Tools and Recommendations for Winona LaDuke's Hemp Farm and Sovereign Native American Tribes (Task Force Report), University of Washington, Washington, DC, USA.

Choi, K. H., Kim, A. R., and Cho, B. U. (2016). "Effects of alkali swelling and beating treatments on properties of kraft pulp fibers," BioResources 11(2), 3769-3782. DOI: 10.15376/biores.11.2.3769-3782

Conard, C. (1994). "The house that hemp built," in: Hemp: Lifeline to the Future, Creative Xpressions, El Cerrito, CA, USA, pp. 3-13.

Crônier, D., Monties, B., and Chabbert, B. (2005). "Structure and chemical composition of bast fibers isolated from developing hemp stem," Journal of Agricultural and Food Chemistry 53(21), 8279-8289. DOI: 10.1021/jf051253k

Crop, N. B. (1938). "New billion-dollar crop," Popular Mechanics Magazine 69(2), 4-5.

Danielewicz, D., and Surma-Ślusarska, B. (2010). "Processing of industrial hemp into papermaking pulps intended for bleaching," Fibres and Textiles in Eastern Europe 18(6), 110-115.

Danielewicz, D., and Surma-Ślusarska, B. (2011). “Oxygen delignification and bleaching of industrial hemp pulps," Fibres and Textiles in Eastern Europe 19(1), 84-88.

De Assis, T., Reisinger, L. W., Pal, L., Pawlak, J., Jameel, H., and Gonzalez, R. W. (2018). "Understanding the effect of machine technology and cellulosic fibers on tissue properties - A review," BioResources 13(2), 4593-4629. DOI: 10.15376/biores.13.2.DeAssis

De Groot, B., Van Dam, J. E. G., Van Der, Z. R. P., and Riet, K. V. (2009). “Simplified kinetic modelling of alkaline delignification of hemp woody core," Holzforschung 48(3), 207-214. DOI: 10.1515/hfsg.1994.48.3.207

Desai, A. N., and Kant, R. (2016). "Geotextiles made from natural fibres," in: Geotextiles: From Design to Applications, Elsevier, Amsterdam, Netherlands, pp. 61-87.

Diesen, M. (1998). "Main characteristics of the global pulp and paper industry," Economics of the Pulp and Paper Industry, $2^{\text {nd }}$ Edition, M. Diesen (ed.), Finnish Paper Engineers' Association, Helsinki, Finland, pp. 9-17.

Edyta, M., Piotr, P., Marcin, D., and Kamila, B. (2015). "Comparison of papermaking potential of wood and hemp cellulose pulps," Forestry and Wood Technology 91, 134-137.

Ervasti, I., Miranda, R., and Kauranen, I. (2016). "A global, comprehensive review of literature related to paper recycling: A pressing need for a uniform system of terms and definitions," Waste Management 48(2), 64-71.

Food and Agricultural Organization (FAO) (1996). The Outlook for Pulp and Paper to 1995. Paper Products, and Industrial Update, Food and Agricultural Organization of the United Nations, Rome, Italy.

Food and Agriculture Organization of United Nations:Technical Report. (1980). Pulping and paper-making properties of fast growing plantation wood species. Rome, Italy.

Fike, J. (2016). "Industrial hemp: Renewed opportunities for an ancient crop," Critical Reviews in Plant Sciences 35(5-6), 406-424. DOI: 10.1080/07352689.2016.1257842

Fischer, W. J., Mayr, M., Spirk, S., Reishofer, D., Jagiello, L. A., Schmiedt, R., Colson, J., Zankel, A., and Bauer, W. (2017). "Pulp fines-characterization, sheet formation, and comparison to microfibrillated cellulose," MDPI Polymers 9, Article Number 366. DOI: $10.3390 /$ polym 9080366

Gandolfi, S., Ottolina, G., Riva, S., Fantoni, G. P., and Patel, I. (2013). “Complete 
chemical analysis of carmagnola hemp hurds and structural features of its components," BioResources 8(2), 2641-2656. DOI: 10.15376/biores.8.2.2641-2656

Gierer, J., and Forest, S. (1980). "Chemical aspects of kraft pulping," Wood Science and Technology 14(4), 241-266. DOI: 10.1007/BF00383453

Gigac, J., and Fišerová, M. (2008). "Influence of pulp refining on tissue paper properties,” TAPPI Journal 7(8), 27-32.

González, I., Boufi, S., Pélach, M. A., Alcalá, M., Vilaseca, F., and Mutjé, P. (2012). "Nanofibrillated cellulose as paper additive in Eucalptus pulp," BioResources 7(4), 5167-5180. DOI: 10.15376/biores.7.4.5167-5180

Grossman, S. R. (1977). "Fibrous webs with improved bonder and creping adhesive," U.S. Patent, No. US4063995.

Gümüşkaya, E., Usta, M., and Balaban, M. (2007). "Carbohydrate components and crystalline structure of organosolv hemp (Cannabis sativa L.) bast fibers pulp," Bioresource Technology 98(3), 491-497. DOI: 10.1016/j.biortech.2006.02.031

ISO 12625-8:2010(E) (2010). "Tissue paper and tissue products- Water-absorption time and water-absorption capacity, basket-immersion test method," International Organization for Standardization, Geneva, Switzerland.

Jani, S. M., Rushdan, I., Saad, M. J., and Ibrahim, R. (2016). "Mechanical properties of beating pulp and paper from rice straw," Journal of Tropical Agriculture and Food Science 44(1), 103-109.

Jansson, J. (2015). The Influence of pH on Fiber and Paper Properties, Master's Thesis, Karlstad University, Karlstad, Sweden.

Johansson, A. (2011). Correlations Between Fibre Properties and Paper Properties, Master's Thesis, KTH Royal Institute of Technology, Stockholm, Sweden.

Johnson, P. (1999). "Industrial hemp: A critical review of claimed potentials for Cannabis sativa," TAPPI Journal 82(7), 113-123.

Johnson, R. (2018). Hemp as an Agricultural Commodity, Congressional Research Service Report, Washington D.C., USA.

Lower, G. A. (1937). "Flax and hemp: From the seed to the loom," Mechanical Engineering Magazine 1(2), Retrieved from (https://www.hempbasics.com/shop/hemp-from-seed-to-loom).

Lusby, G. R., and Mass, O. (1937). "The delignification of wood by strong alkaline solutions," Canadian Journal of Research 15b(12), 536-544. DOI: 10.1139/cjr37b058.

Musio, S., Müssig, J., and Amaducci, S. (2018). "Optimizing hemp fiber production for high performance composite applications." Frontiers in Plant Science 871(November), 1-14.

Richard, B. (2003). “Antibacterial toilet tissue,” U.S. Patent No. US20030143372A1.

Santos, R. B., Jameel, H., Chang, H., and Hart, P. W. (2013). "Impact of lignin and carbohydrate chemical structures on degradation reactions during hardwood kraft pulping processes" BioResources 8(1), 158-171. DOI: 10.15376/biores.8.1.158-171

Schluttenhofer, C., and Yuan, L. (2017). "Challenges towards revitalizing hemp: A multifaceted crop," Trends Plant Science 22(11), 917-929. DOI:

10.1016/j.tplants.2017.08.004

Schuchardtl, D. R., and Berg, J. C. (1991). "Liquid transport in composite cellulose superabsorbent fiber networks," Wood and Fiber Science 23(3), 342-357.

Shatalov, A. A., and Pereira, H. (2006). "Papermaking fibers from giant reed (Arundo donax L.) by advanced ecologically friendly pulpimng and bleaching technologies," 
BioResources 1(1), 45-61. DOI: 10.15376/biores.1.1.45-61

Shelp, G., Young, S., Simpson, M., Hutfluss, L., Wright, T., Potter, F., and Breyer, R. (2017). "Strong feelings for softness: A comparative study of US towel production," in: Tappi Tissue Conference 2017, Miami, FL, USA, pp. 1-15.

Small, E., Pocock, T., and Cavers, P. B. (2003). "The biology of Canadian weeds. 119. Cannabis sativa L.," Canadian Journal of Plant Science 83(1), 217-237. DOI: 10.4141/P02-021

Stevulova, N., Cigasova, J., Estokova, A., Terpakova, E., Geffert, A., Kacik, F., Singovszka, E., and Holub, M. (2014). "Properties characterization of chemically modified hemp hurds," Materials 7(12), 8131-8150. DOI: 10.3390/ma7128131

TAPPI T205 sp-02 (2006). "Forming handsheets for physical tests of pulp," TAPPI Press, Atlanta, GA, USA.

TAPPI T222 om-11 (2011). “Acid-insoluble lignin in wood and pulp,” TAPPI Press, Atlanta, GA, USA.

TAPPI T227 om-99 (1999). "Freeness of pulp (Canadian standard method)," TAPPI Press, Atlanta, GA, USA.

TAPPI T236 om-99 (2006). "Kappa number of pulp,” TAPPI Press, Atlanta, GA, USA.

TAPPI T258 om-02 (2006). "Basic density and moisture content of pulpwood," TAPPI Press, Atlanta, GA, USA.

TAPPI T456 om-03 (2003). "Tensile breaking strength of water-saturated paper and paperboard ('wet tensile strength')," TAPPI Press, Atlanta, GA, USA.

TAPPI T460 om-02 (2006). "Air resistance of paper (Gurley method)," TAPPI Press, Atlanta, GA, USA.

TAPPI T494 om-01 (2006). "Tensile properties of paper and paperboard (using constant rate of elongation apparatus)," TAPPI Press, Atlanta, GA, USA.

Trent, N. (2019). Tissue Paper Market 2019 Global Industry Sales, Supply, Demand and Consumption and Forecast to 2024 (Market Report), Marketwatch, Pune, India

Article submitted: September 22, 2019; Peer review completed: November 17, 2019;

Revised version received: November 29, 2019; Accepted: December 1, 2019; Published: December 4, 2019.

DOI: $10.15376 /$ biores.15.1.706-720 